\title{
II. Bayezid Dönemi muhasebe uygulamaları ve Osmanlı mali düzeninde yaşanan gelişmeler: Fatih Camii ve İmareti tesislerinin gelir giderleri
}

\author{
Dr. Öğretim Üyesi Fırat ALTINKAYNAK ${ }^{\mathrm{a}}$
}

aMalatya Turgut Özal Üniversitesi, İşletme ve Yönetim Bilimleri Fakültesi, , e posta: firat.altinkaynak@ozal.edu.tr, Orcid: 0000-0003-0960-2254

MAKALE BILGILERi

Araştırma Makalesi

Geliş Tarihi 17 Kasım 2020

Kabul tarihi 26 Kasım 2020

\section{ARTICLE INFO}

Research Article

Received 17 November

2020

Accepted 26 November

2020

\section{Özet}

II. Bayezid döneminde yaşanan bir takım siyasi gelişmeler, iktisadi ve mali düzene ilişkin bazı yapısal düzenlemeleri beraberinde getirmiştir. Bu gelişmelerle birlikte ortaya çıkan kayıt ve denetim ihtiyacı ise Osmanlı Devleti muhasebe uygulamalarında Fatih Sultan Mehmed döneminde kaydedilen gelişmenin II. Bayezid döneminde de devam etmesini sağlamıştır. Bu çalışmada II. Bayezid dönemindeki gelişmeler doğrultusunda muhasebenin tarihsel sürecinde Osmanlı Devleti'nin yeri ve öneminin vurgulanması amaçlanmıştır. Bu amaç doğrultusunda çalışmada öncelikle II. Bayezid dönemindeki ticari hayat ve mali yapı paralelinde devlet muhasebe düzenindeki gelişmelere genel hatları ile değinilmiştir. Daha sonra Fatih Camii ve İmareti Tesislerinin vakıf kayıtları incelenerek vakfın 1489-1490 yıllarına ait gelir ve giderleri sınıflandırılmış ve bu gelir-giderlerin günümüz finansal raporlama çerçevelerindeki durumu ele alınmıştır.

Anahtar Kelimeler: Muhasebe Tarihi, Osmanlı Devleti Muhasebe Uygulamaları, Fatih Camii ve İmareti Tesislerinin Gelir Giderleri

Developments in accounting practices and Ottoman fiscal order in the Bayezid II Period: income and expense of Fatih Mosque and Immaret's facilities

\section{Abstract}

Some political developments that took place during the Bayezid II period brought some structural arrangements regarding the economic and fiscal order. The need for recording and auditing that emerged with these developments enabled the development of the accounting practices of the Ottoman Empire during the reign of Sultan Mehmed the Conqueror to continue in the period of Bayezid II. In this study, it is aimed to emphasize the place and importance of the Ottoman Empire in the historical process of accounting in line with the developments in the period of Bayezid II. In line with this purpose, in this study, the developments in the government accounting system in parallel with the commercial life and fiscal structure during the Bayezid II period were discussed in general terms. Afterwards, the foundation records of Fatih Mosque and Imaret's Facilities were examined and the income and expenses of the foundation for the years 1489-1490 were classified and the situation of these income-expenses in today's financial reporting frameworks was discussed.

Key Words: Accounting History, Accounting Practices of the Ottoman State, Income and Expense of Fatih Mosque and Immaret's Facilities

\section{Giriş}

Osmanlı devlet muhasebe düzeni ve mali örgütlenmesinin teşekküllüne ilişkin önemli gelişmelerin yükselme döneminin ilk yıllarına karşılık gelen XV yüzyılın ikinci yarısında yaşandığını söylemek mümkündür. Özellikle de Fatih Sultan Mehmed döneminde çıkarılan Kanunname-i Ali Osman, Kanun-ı Padişah, Gümrük Kanunu gibi yasal düzenlemelerle başlayan bu teşekkül sürecinin II. Bayezid döneminde de (1481-1512) devam ettiği bilinmektedir (Küçüker, 2019: 80). Zira ticaretin II. Bayezid dönemindeki gelişen seyri özellikle de devlet muhasebesi açısından kayıt fonksiyonun gelişimini de beraberinde getirmiştir. Diğer taraftan ticari gelişmelere sahne olsa da II Bayezid döneminde ekonomik sıkıntıların yaşandığı da bilinmektedir. Bu durum ise vergi konusunda çeşitliliğin artması ile neticelenmiştir. Vergilerin sayıca ve miktarca artması ise özellikle de denetim ve mali organizasyonun güçlenmesini beraberinde getirmiştir. Muhasebe düzeni, iktisadi ve ticari hayat ile mali yapının gelişimi neticesinde; Il. Bayezid döneminden, merdiven yöntemi ile tutulan muhasebe kayıtları, çeşitli muhasebe defterleri ve gelir-gider cetvelleri gibi Osmanlı muhasebesinin tarihsel sürecine ışık tutacak birtakım belgeler günümüze kadar ulaşmıştır. Bu belgelerden birinin de Fatih Camii ve İmareti Tesislerinin vakıf kayıtları olduğunu söylemek mümkündür.

Illk kez Barkan (1963) tarafından tetkik edilen Fatih Camii ve İmareti Tesislerinin vakıf kayıtları incelendiğinde 1489-1490 yıllarına ait gelir ve giderlerin belirli bir düzen ve sınıflandırma içerisinde bütün ayrıntıları ile kaydedildiği görülmüştür. Fatih Camii ve İmareti Tesislerinin muhasebe kayıtları iki ana bölümden oluşmaktadır. Birinci bölümde vakfın yıllık ana gelir ve giderler kalemleri yer alırken; ikinci bölümde ise köylerdeki mahsullerden tahsil edilen gelirlerin miktar ve türlerine ait olan ambar hesapları mevcuttur (Barkan, 1963: 300-302). Bu çalışmada Barkan' ın (1963) “Fatih Camii ve Imareti Tesislerinin $1489-1490$ Yıllarına ait Muhasebe Bilançoları" adlı çalışması esas alınarak vakıf kayıtlarının ilk bölümündeki yıllık gelir ve gider kayıtları ele alınmıştır. Çalışmada, vakfın yıllık gelir ve giderleri sınıflandırılarak bu gelir ve giderlerin günümüz finansal raporlama çerçevelerindeki durumu incelenmiştir.

\section{Bayezid Döneminde Ticari Hayat, Mali Yapı ve Devlet Muhasebe Uygulamalarındaki Gelişmeler}

XV. yüzyıl, Osmanlı Devleti için siyasal, sosyal ve kültürel birtakım gelişmelere sahne olduğu gibi iktisadi ve mali açıdan da önemli gelişmelerin yaşandığı bir dönemi teşkil etmektedir. Özellikle de Fatih Sultan Mehmet ve II. Bayezid'in hüküm sürdüğü, yüzyılın ikinci yarısındaki gelişim süreci Osmanlı Devleti’ni gerek siyasi gerekse iktisadi ve mali açından önemli bir seviyeye taşımıştır. Bu iktisadi ve mali gelişmişliğin muhasebe uygulamaları ve kayıt düzeninde de kendisini gösterdiğini söylemek mümkündür. Ancak özellikle de II. Bayezid döneminde muhasebe uygulamalarındaki gelişimin ticaretteki gelişmelerle paralellik arz ettiğini söylemek mümkündür. Zira Osmanlı Devleti'nde özelliklede İstanbul'un fethi ile başlayarak XVI. yüzyılın sonlarına kadar devam eden süreçte ticari açıdan kayda değer gelişmelerin yaşandığı bilinmektedir.

Osmanlı Devleti'nin daha önceleri Bizanslıların elinde olan ve en önemli yerleşim yerlerinden olan Bursa ve İznik'e sahip olması ve özellikle de XV. yüzyıl ortalarından itibaren İstanbul ve Marmara hattında genişlemesi bu bölgedeki iktisadi yapı ve ticari düzenden istifade etmelerini sağlamıştır Öte yandan Osmanlı Devleti'nin ticari uygulamaları bu iktisadi yapının daha da gelişmesini beraberinde getirmiştir (Uzunçarşıı, 1983: 681). Zira yükseliş döneminde 1483 yılında İstanbul limanına ticari amaçı 2019 gemi ve 2265 mavna yanaşmıştır. (İnalcık, 2015: 301) Bu bilgi bile söz konusu dönemde ticarette yaşanan canlılığın bir göstergesi olarak kabul edilebilir. Bununla birlikte Bursa'nın ticari açıdan önemi Bizans dönemine nispetle çok daha fazla artmıştır. Her türlü mallar, beyaz sabunlar, yün ve pamuklu kumaşlar, ipekler, vb. ürünler dışarıdan gelen tüccarlara satılmaktaydı. Floransa, İspanya ve Cenevizli tüccarların yanı sıra Suriye'den gelen hacı kafileleri sağlanan büyük kolaylıklarla alışverişlerini rahatlıkla yapmaktaydı (Uzunçarşılı, 1983: 681). 
II. Bayezid döneminde ticaretin özellikle de tekstil üretimi ile birlikte geliştiği ve tekstil ticaretinin Osmanlı hazinesinin önemli gelir kaynaklarından biri olduğu bilinmektedir. 1300-1600 yılları arasında Anadolu'nun en önemli tekstil üretim bölgelerinden biri olması özellikle de Bursa'nın bir ticaret merkezi haline gelmesini beraberinde getirmiştir. Bursa ve çevresinde üretilen sof kumaşlar ve değerli kemhalar; i̇talyan ve Fransız kraliyet ailelerinin, Rus Çarlarının ve İsveç piskoposlarııın da aralarında bulunduğu Avrupalı seçkinler tarafından satın alınmaktaydı. XV. Yüzyıl sonlarına doğru ise ticaretin özellikle ipek üzerine yoğunlaştığı ve 1487-1513 yılları arasında, Bursa'da ham ipek üzerinden alınan vergi gelirlerinin toplamııı 6 milyon akçaya ulaştığı bilinmektedir (İnalcık, 2015: 301-305). XV. Yüzyıl Bursa şer'iye sicilleri özellikle İranlı (Acem) tüccarların da Bursa'da oldukça yoğun ticari faaliyetlerde bulunduğunu göstermektedir. Zira hem güvenilir olması hem de tacirler için rahat ve kolay alışveriş imkânı sağlaması Bursa hanlarını özellikle de İran tacirleri için cazip ticaret merkezleri haline dönüştürmüştür. Hatta Sultan II. Bayezid tarafından 1490 yılında inşa ettirilen ve dönemin en büyük hanlarından biri olan Koza-Hanı o zamanlarda Acem Hanı olarak adlandııımaktaydı. Ayrıca belirtmek gerekir ki; söz konusu dönemde Bursa yalnızca İranlı tüccarlar için değil aynı zamanda Ceneviz, Floransa ve Venedik tüccarları için de bir ticaret merkezi halindedir. Bursa kadı defterleri incelendiğinde bu tüccarların ticaret usul ve ticari muameleleri hakkında da bilgi etmek mümkündür. Kadı defterlerindeki vesikalardan, ticari işlemlerin genellikle 3-6-12 aylık kredilerle yapıldığı ve borçlar için kefil belirlenmesinin veya rehin verilmesinin gerekli olduğu anlaşılmaktadır. Ayrıca İtalyan tacirlerin ipek bedellerini genellikle getirdikleri yünlü kumaşlarla takas ettiği ancak bazen gümüş veya altın ile ödedikleri de ilgili vesikalardan anlaşılmaktadır (İnalcık, 2009: 209-211).

İpek ticareti açısından Bursa bir merkezi teşkil etse de Azak ve Kefe de ipek ticaretinin yoğun olarak gerçekleştiği bölgelerdir. Zira özellikle de Cenevizlilerin ipek ihtiyacını Azak ve Kefe'den karşıladıkları da bilinmektedir (Öztürk, 2000: 480). Bunula birlikte Yakındoğu üzerinden Bursa ve İstanbul'a ulaşan ipeğin önemli bir bölümü Kili, Akkirman ve Kefe vasıtası ile kuzey ülkelerine ihraç edilmekteydi (İnalcık, 1996: 123, Aktaran, Öztürk, 2000: 481). Özellikle de Kefe'nin ipek ticareti için ihraç kapısı olmasının ötesinde kendi ipek üretimini geliştirdiği de bilinmektedir (Öztürk, 2000: 480).

Osmanlı Devleti söz konusu dönemde ticarette önemli gelişmelere sahip olsa da büyük ticari kuruluş ve organizasyonlarının teşekkülünün gerçekleşmediğini de belirtmek gerekmektedir. Zira üretim, mutlak merkeziyeti yapıya sahip bir yönetim anlayışı ile merkezi iradeye kesin kurallarla bağlanmış durumdadır. Serbest piyasa koşullarııın oluşmadığı bu ortamda üretim standartlarııı tespitinden fiyatların belirlenmesi ve kâr oranlarının sınırlandırımasına kadar bütün süreçlerin devlet tarafından uygulanması ve kontrol edilmesi Osmanlı Devleti'nde yüksek sermaye gruplarının oluşumuna engel teşkil etmiştir. (Öztürk, 1999: 140-142). Büyük ticari kuruluşlarının geliştirilememesinin ardında yatan bir başka etken ise Osmanlı Devleti'nde İslami İktisadi yapının hâkim olmasıdır. Gereğinden fazla kâr elde edilmesinin İslam dinine göre hoş karşılanmaması ve faiz uygulamasının yasaklanmış olması sebebi ile vadeli alım satım işlemlerinin gerçekleştirilmesinde karşılaşılan sorunlar da yüksek sermaye gruplarının teşekkülünü zorlaştırmıştır (Güvemli, 1998: 10-11).

Osmanlı Devleti kuruluşundan itibaren değişen iktisadi şartlar çerçevesinde çeşitli mali yöntem ve uygulamalar geliştirmiştir. Bu mali uygulamalar kapsamında vergiler, özellikle de XVI. yüzyıl sonlarına kadar "reaya-askeri-merkez" üçlü ilişkisinin merkezine yerleştirilmiştir. Ayrıca bu mali esneklik açısından vergiler bazen nakdi olarak bazen de bedel olarak tahsil edilmiştir. Ancak iktisadi koşullardaki değişime paralel olarak vergilerin zamanla bedel olarak tahsil edilmeye başlandığı da bilinmektedir (Taş, 2010: 310). Osmanlı mali yapısındaki vergiler şer'i ve örfî olarak iki kısım altında toplanmıştır. Cizye, zekât, öşür, haraç ve bunların kısımları şer'i vergiler olarak toplanmaktaydı. Tekâlif-i örfiyye adı verilen örfi vergiler ise ilk defa Sultan II. Bayezid zamanında avarız vergisi adı altında olağanüstü zamanlarda, hükümdarın emriyle toplanan bir vergi olarak bilinmektedir (Halaçoğlu, 1991: 56). Güvemli (1998: 122) ise söz konusu dönemde devletin gelirlerinin önemli bir bölümünü oluşturan ve vergileri aşağıdaki gibi sınıflandırmıştır:

- Araziden ve tarımsal üretimden alınan vergiler

- Esnaf ve sanatkâr vergileri

- Gayrimüslimlerden alınan vergiler

- Gümrük vergileri

- Hayvan vergileri

- Pazar yerinden alınan vergiler

II. Bayezid'in kendinden önce hüküm süren babası Fatih Sultan Mehmet gibi mali konularla ilgili düzenlemelere önem verdiğini söylemek mümkündür (Küçüker, 2019: 80). Ancak II. Bayezid ve Kardeşi Cem Sultan arasında yaşanan uzun süreli taht mücadelesi bir takım mali sorunların yaşanmasına da neden olmuştur (Güvemli, Toraman ve Güvemli, 2015: 262). Daha önce örneğine rastlanmamış olan ve "yağma hakkı" olarak adlandırılan ödemelerin söz konusu mali sorunların yaşanmasındaki en önemli neden olduğunu belirtmek gerekmektedir. Yeniçerilerin Cem Sultan'dan sonra ayaklanıp Bursa'yı yağmalamaya kalkışması neticesinde Sultan II. Bayezid Bursa'nın önemli bir ticaret merkezi olması ve devletin ilk başkenti olması nedenleri ile askerlerin elde edeceği tahmini yağma kazancını hesaplatıp ödemeyi kabul etmiştir. Yeniçerilere şehri yağmalamaktan vazgeçmeleri için 1.000 akçe ödeme yapıldığı bilinmektedir. Yeniçerilere ödenen bu para "yağma hakkı muhassesatı" olarak da bilinmektedir (Sayar, 1978: 69-70).

Ticaretteki gelişmelere rağmen Cem Sultan ile olan mücadele iktisadi açıdan birtakım sorunların yaşanmasına neden olmuştur. Öyle ki II. Bayezid döneminde Osmanlı Akçesi tarihte ilk defa değer kaybetmiştir. Fatih Sultan Mehmet zamanında 1 altın sikke yaklaşık 45 akçeye tekabül ederken, II. Bayezid döneminde 1 altın sikke yaklaşık 60 akçeye yükselmiştir (Güvemli, Toraman ve Güvemli, 2015: 262). íktisadi açıdan yaşanan sorunlar neticesinde vergilere ağırlık verildiğini söylemek mümkündür. II. Bayezid döneminde örfi vergiler adı altında çok sayıda vergi toplandığı da bilinmektedir. Bu vergilerden bazıları aşağıdaki gibi sıralanabilir (Sayar, 1978: 70-76):

- "Hudus-u Avarız Vergisi": II. Bayezid döneminde yaşanan siyasal gelişmelerden kaynaklanan iktisadi ve mali sorunlar "küçük kıyamet" olarak bilinen İstanbul depremi ve sarayda gerçekleştirilen gereksiz harcamalar neticesinde daha da büyümüş ve para gereksinimi artmıştır. Bu gereksinimin karşılanması adına toplanmaya başlanan vergisi ile her haneden iki akçe nakit ve yirmi haneden bir hizmetli alındığı bilinmektedir. "Hudus-u Avarız" Hem ayni hem de nakdi özelliğe sahip bir vergi türüdür.

- “imdadiye-i Seferiye": Özellikle savaş dönemlerinde savaş ile ilgili masrafların karşıllanması için toplanan bir vergidir. İmdadiye-i Seferiye II. Bayezid döneminde sadece savaş dönemlerinde değil, sürekli olarak toplanmaya başlanmıştır. Bu nedenle verginin adı "İmdadiye-i Hazeriye" olarak değişmiştir.

- "Tayyarat": Havadan gelirler anlamına gelmektedir. Planlanmayan giderlerin karşılanması için halktan tahsil edilen bir tür örfi vergidir.

- “ianat": Deprem, yangın, sel gibi doğal afetlerde zarar gören vilayetler için diğer vilayetlerdeki mükelleflerden toplanan vergilerdir.

- “izni Sefine Harcı”: Örfi vergilerden biri olan İzni Sefine Harcı Osmanlı Devleti'nin hâkim olduğu boğazlardan geçen gemilerden büyüklükleri nispetiyle farklı miktarlarda alınan bir vergidir.

- "Baç, Yasak, Yol, Mürûriye Resimleri”: Tüccarların geçtiği kapı ve geçitlerin bakım onarım masraflarının karşılanması için toplanan vergilerdir. Yüksüz hayvanlardan 20, yüklü hayvanlardan 40 ve arabalardan 80 akçe alındığı bilinmektedir. Sonraki yıllarda yabancı tüccarlar bu durumdan şikayetçi olmuş ve bir defaya mahsus olarak ilk geçitte 300 akçe alınması konusunda anlaşılmıştır. Bu durum kapitülasyonların başlangıcı olarak da kabul edilmektedir. Yerli tüccarlar ise her geçişte ödemeye devam etmiştir.

- "Ferman Harcı ve Kaftan Bedeli”: Vezir, kadı, vali gibi yüksek mertebedeki memurların tayin işlemleri için yazılan fermanlardan alınan harçlar ve giydikleri kaftanların masrafları için toplanan bir örfi vergi türüdür.

- "Beygir, Mürûr ve Ubûr ve Daire Masrafı": Akeri ve mülki memurların devleti temsil ederken çıktıkları seyahat ve konaklama masraflarının karşılanması için tevzi defterlerinde tahakkuk ettirilip tahsil edilen vergilerdir.

- “iane-i Hükkamiye, Mübaşiriye, Kalemiye, Katibiye... Harçları”: Hâkim, mübaşir, kâtip kalemi, tahsildar vb. memurların geçimlerinin karşılanması için bu adlarla tevzi defterlerinde tahakkuk ettirilip tahsil edilen vergilerdir.

- "Kürekciyan Avarızı": Gemilerde kürek çekmek ve yelken açmak gibi işleri yürüten gemi personeli giderlerinin karşılanması için toplanan vergidir.

- "Faiz, Senelik Nema, Güzeşte, Sarrafiye Harcı”: Gelirlerin tahsil edilmesinden önce gerçekleşen kamu giderlerinin karşılanmasıı için hazineye verilen ödünç para ve bu paranın faizi tevzi defterlerine kaydedilerek mükelleflerden tahsil edilmektedir.

- "Bab-ı Ali Tamirat ve Teşrifatı": Vilayetlerdeki hükümet binalarının tamiri ve düzenlenmesi için yapılan harcamalar için alınan bir tür örfi vergidir.

- "Diyet Öşürü": Bir kimsenin ölümüne ya da yaralanmasına sebep olan kişilerden, ölen ya da yaralı olan kimsenin yakınlarına (varislerine) verilmek üzere alınan bedelin onda birine karşılık gelen kısmıdır. 
II. Bayezid döneminde ticarette yaşanan gelişmelerin yanı sıra vergi çeşitliliğindeki artış ve vergilerin hesaplanması, tahsil edilmesi gibi süreçlerin takibi, Osmanlı Devleti denetim organizasyonunun da gelişimini beraberinde getirmiştir. Osmanlı Devleti’nin mali denetim organizasyonun gücü konusunda ise II. Bayezid döneminde yaşanan bir olay önem arz etmektedir. II. Bayezid'in kızı Ayşe Sultan'ın Kütahya'da bulunduğu sırada Cem Sultan'a karşı mücadele ettiği tarihçiler tarafından belirtilmektedir. Cem Sultan'ın bölgeye geldiği tarihlerde Ayşe Sultan'ın kocası olan Anadolu Beylerbeyi Sinan Paşa Kütahya'da değildir. Bu nedenle Ayşe Sultan yetkisi dışında kalenin kasasından 25.000 akçe almak zorunda kalmış ve zaruri nedenlerle alınan paranın belirli bir kısmıyla kale onarılmış, kalan kısmı da mücadele için askerlere verilmiştir. Aradan belirli bir süre geçtikten sonra Ayşe Sultan Gelibolu'ya yerleşmiştir. Ancak Osmanlı merkez mali teşkilatı, yetkisi olmadan aldığı bu parayı Ayşe Sultan'dan geri istemiştir. Mali idarenin isteği neticesinde Ayşe Sultan babası II. Bayezid'e bir mektup yazarak söz konusu paranın kalenin onarımı için kullanıldığını belirtmiş ve buna rağmen affını istemeyip borcunu ödemek istemiştir. Topkapı arşivlerinde bulunan bu mektup Osmanlı siyasi tarihi açısından olduğu kadar Türk muhasebe ve denetim tarihi açısından da önem arz etmektedir. Özellikle de Osmanlı Devleti'nin mali denetim organizasyonu ve bu organizasyonunun gücü konusunda Ayşe Sultan'ın mektubunun döneme ışık tuttuğunu belirtmek gerekmektedir. (Uluçay, 1959: 119; Güvemli vd. 2015: 263). Sultan II. Bayezid’in kızı Ayşe Sultan'ın yaşamış olduğu olay ve neticesinde yazmış olduğu mektup, devlet yöneticileri ve ailelerinin devlet hazinesine karşı olan tutumları ve Osmanlı Devleti'nde denetçi olarak görev yapan memurların iş takibi ve ciddiyetleri açısından da önem arz etmektedir. Osmanlı muhasebe kayıtlarının ve defterlerinin mevcudiyeti için bir delil niteliğinde olan Ayşe Sultan'ın mektubu aynı zamanda denetim fonksiyonunun yükselme dönemi başlarındaki gelişmişlik düzeyi hakkında da bilgi vermektedir (Güvemli, Toraman ve Güvemli, 2015: 263-264). Ayşe Sultan'ın yazdığı mektup özellikle devletin milletle hesaplaşması bağlamında da ele alınabilir devlet yöneticilerinin ve ailelerinin yapmış olduğu kamu harcamalarının bile sıkı bir şekilde takip edilmesi ve devlet hazinesine karşı olan borçların tespit edilerek ödenmesinin istenmesi hesap verebilirlik açısından da son derece önemli olduğu söylenebilir (Küçüker, Can ve Demirci, 2018: 605).

\section{Fatih Camii ile İmareti Tesislerinin Hesapları ve Günümüz Finansal Raporlama Çerçevelerine Uyarlanması}

Osmanlı mali organizasyonu ve devlet muhasebe sisteminin teşekkülüne ilişkin en önemli gelişmelerin XV. yüzyılın ikinci yarısında yaşandığını söylemek mümkündür. Özellikle de Fatih Sultan Mehmet devrinde çıkarılan kanunnameler, defterdarlık teşkilatı ve muhasebe kadrolarının oluşumunu ve güçlendirilmesini sağlamıştır. Ayrıca ücretler ve vergi türleri, oranları, miktarları ve tahsil yetkilileri de bu süreçteki yasal düzenlemelerle belirlenmiştir. Bununla birlikte özellikle de mali yapıya ilişkin yasal düzenlemelerin II. Bayezid döneminde de devam ettiğini belirtmek gerekmektedir. II. Bayezid döneminde gerek ticarette yaşanan gelişmeler gerekse mali sıkıntılar sebebi ile ortaya çıkan vergilerin hesaplanma ve tahsil edilme süreçleri kayıt ihtiyacını ortaya çıkarmıştır. Zira merdiven yöntemi ile tutulan muhasebe kayıt örneklerine, çeşitli muhasebe defterlerine ve gelir-gider cetvelleri örneklerine bu dönemde rastlamak mümkündür (Küçüker, 2019: 230). Fatih Camii ve İmareti Tesisleri'nin muhasebe kayıtları da bu örneklerden biri olarak II. Bayezid dönemi muhasebe uygulamalarında yaşanan gelişmelere ışık tutmaktadır. Osmanlı Devleti mali idaresinin esas defterlerinden biri olarak kabul edilen bu önemli kaynakta Fatih Camii ve İmaretinin yılık gelir ve giderleri belirli bir düzen ve sınıflandırma içerisinde bütün ayrıntıları ile kaydedilmiştir (Küçüker, 2019: 83).Türkiye'de iktisat tarihi biliminin kurucularından sayılan ve Türkiye'nin en önemli iktisat ve hukuk tarihçilerinden biri olan Ömer Lütfi Barkan'ın bu konuya ilişkin olarak kaleme aldığı "Fatih Camii ve İmareti Tesislerinin 1489-1490 Yıllarına ait Muhasebe Bilançoları” adlı çalışmada bu kayıtlar ayrıntılı olarak incelenmiştir.

1489-1490 yıllarına ait bilanço açıklamalarından; yıllık hesapların kesin ve son şekillerinde, maliye idaresinin ana defterlerine kayıt tarihlerinin mevcut olduğu anlaşılmaktadır. Bu tarih esasen Divan'ın kayıtları inceleme ve kabul etme tarihi olarak da kabul edilebilir. Bununla beraber 1489 yılı hesaplarının "Hayreddin", 1490 yılı hesaplarının ise "Bâli" isimli kâtipler tarafından kaydedildiği de açıklamalardan anlaşılmaktadır. Fatih Camii ve İmareti Tesislerinin muhasebe kayıtları genel olarak iki ana bölümde ele alınmıştır. Birinci bölümde vakfın yıllık gelir ve giderleri ana kalemler olarak yer almaktadır. İkinci bölüm ise "muhasebe'i-gallât" olarak isimlendirilmekte ve köylerdeki mahsullerden tahsil edilen gelirlerin miktar ve türlerine ait olan ambar hesapları yer almaktadır (Barkan, 1963: 300-302). Bu çalışmada vakfın kayıtlarının birinci bölümündeki yılık gelir ve gider kalemleri ele alınmıştır.

Barkan (1963) tarafından tetkik edilen Fatih Camii ve İmareti Tesislerinin vakıf kayıtlarına göre vakfın kasasına 1489 yılında giren para bir önceki yıl devredilen bakiye ile birlikte 1.535 .536 ve 1490 'da ise 1.459 .989 akça olarak gösterilmiştir. Bu paranın geçen yıllardan bakiye olarak devredilen kısımları 1489 yılı için 34.925 ve 1490 yılı için ise 10.225 akçedir. Yılık muhasebe kayıtlarındaki gelirler faslındaki tür ve miktarları ise dört ana kalemde aşağıda sıralanmıştır (Barkan, 1963: 302):

1. İstanbul'da mevcut 12 hamam ile bazı arsa kiralarından elde edilen gelir:

(1489: 255.233 Akçe) / (1490: 243.893 Akçe)

2. İstanbul ve Galata'da mevcut olup evli erkek ve dul kadın olarak sayıları (1489: 8.667) (1490: 8.385) i bulan Hristiyan ve Yahudilerden alınan cizye: (1489: 433.698 Akçe) / (1490: 421.274 Akçe)

3. Vakfın, Çorlu, Tekfurdağ, Ereğli, Kırklareli ve Edirne kazalarının elliden fazla köyündeki reayanın cizye ve ispençleriyle para halinde tahsil edilen diğer vergilerinden (mahsulden) elde edilen ve miktarı:

(1489: 723.220 Akçe) / (1490: 708.437 Akçe)

4. Geçen seneden kilerde kalan hububat fazlalarından veya bazı uzak köylerden nakli zorluklarından kurtulmak için satışa çıkarılmış olan aşar mahsulü ile ambarda mevcut diğer türlü malzeme artıklarının satışından elde edilen gelir:

(1489: 88.460 Akçe) / (1490: 76.160 Akçe)

Fatih Camii ve İmareti Tesislerinin 1489 yılı giderleri 1.483.931 akçe olup 869.260 akçesi çalışanların maaşlarını oluşturmaktadır. 1.421 .249 akçe olan 1490 yılı giderlerinin ise 923.296 akçesi çalışanların maaşlarını oluşturmaktadır. Geriye kalan giderler ise 5 ana kalemde aşağıda sıralanmıştır (Barkan, 1963: 303):

1. İmarette dağıtılan ekmek ve yemekler için yapılan harcamalar:

(1489: 461.417 akçe) / (1490: 330.803 akçe)

2. Fatih Camii için yapılan masraflar:

(1489: 4.159 akçe) / (1490: 4.690 akçe)

3. Darüşşifada yapılan masraflar:

(1489: 72.000 akçe) / (1490: 72.000 akçe)

4. Müteferrik masraflar:

(1489: 63.432 akçe) / (1490: 13.589 akçe)

5. Tamirler için yapılan harcamalar:

(1489: 13.663 akçe) / (1490: 16.871 akçe)

Fatih Camii ve İmaretinin 1489-1490 yıllarına ait muhasebe kayıtlarında yer alan ana gelir ve gider kalemleri aşağıda tablo halinde sunulmuştur. 
Tablo 1. Fatih Camii ve Imareti tesislerinin 1489-1490 yılları bilançolarında yer alan gelir ve giderler

\begin{tabular}{|c|c|c|c|c|c|}
\hline YILLAR & 1489 & 1490 & \multirow{2}{*}{$\begin{array}{c}\text { YILLAR } \\
\text { GIDERLER }\end{array}$} & 1489 & 1490 \\
\hline GELIRLER & Tutar (Akçe) & Tutar (Akçe) & & Tutar (Akçe) & Tutar (Akçe) \\
\hline Önceki yıldan devreden bakiye & 34.925 & 10.225 & $\begin{array}{l}\text { Vakfın çalışanlarına ödenen } \\
\text { maaşlar. }\end{array}$ & 869.260 & 923.296 \\
\hline $\begin{array}{l}\text { İstanbul'daki } 12 \text { hamam ve bazı arsaların kira } \\
\text { gelirleri }\end{array}$ & 255.233 & 243.893 & $\begin{array}{l}\text { İmarette dağıtılan ekmek ve } \\
\text { yiyecek giderleri }\end{array}$ & 461.417 & 390.803 \\
\hline $\begin{array}{l}\text { İstanbul ve Galata'daki evli erkek ve dul kadın } \\
\text { Hristiyan ve Yahudilerden toplanan cizye gelirleri }\end{array}$ & 433.698 & 421.274 & $\begin{array}{l}\text { Fatih Camii için yapılan } \\
\text { harcamalar }\end{array}$ & 4.159 & 4.690 \\
\hline $\begin{array}{l}\text { Vakfın, Çorlu, Tekfur Dağı, Ereğli, Kırklareli ve } \\
\text { Edirne'de bulunan elliden fazla köyündeki } \\
\text { reayadan toplanan cizye ve ispence vergisi gelirleri } \\
\text { ile para olarak tahsil edilen diğer vergilerden } \\
\text { (mahsulden) elde edilen gelirler. }\end{array}$ & 723.220 & 708.437 & Darüşşifada yapılan masraflar & 72.000 & 72.000 \\
\hline \multirow{2}{*}{$\begin{array}{l}\text { Geçen seneden satılmış olan şeylerden geriye } \\
\text { kalan hububat fazlalarından veya bazı uzak } \\
\text { köylerden nakliye zorluklardan kurtulmak için } \\
\text { satılığa çıkarılmış olan öşür mahsulü ile ambardaki } \\
\text { diğer fazlalıklarının satışından elde edilen gelirler } \\
\text { toplamı }\end{array}$} & \multirow[b]{2}{*}{88.460} & \multirow[b]{2}{*}{76.160} & Müteferrik giderler & 63.432 & 13.589 \\
\hline & & & Tamirat giderleri & 13.663 & 16.871 \\
\hline \multirow[t]{3}{*}{ TOPLAM } & 1.535 .536 & 1.459 .989 & TOPLAM & 1.483 .931 & 1.421.249 \\
\hline & \multicolumn{3}{|c|}{1489 Yılı } & \multicolumn{2}{|c|}{1490 Yılı } \\
\hline & \multicolumn{3}{|c|}{$\begin{array}{c}\mathbf{5 1 . 6 0 5} \text { Akçe } \\
(1.535 .536-1.483 .931)\end{array}$} & \multicolumn{2}{|c|}{$\begin{array}{c}\text { 38.740 Akçe } \\
(1.459 .989-1.421 .249)\end{array}$} \\
\hline
\end{tabular}

Kaynak: (Barkan, 1963: 297-341'den uyarlayan Küçüker, 2019: 84).

Fatih Camii ve İmareti Tesislerinin 1489-1490 yıllarına ait gelirleri ile bu gelirlerin Muhasebe Sistemi Uygulama Genel Tebliği (MSUGT), Türkiye Muhasebe Standartları (TMS) ve Türkiye Finansal Raporlama Standartları (TFRS) çerçevesinde raporlanacağı hesap sınıfları aşağıdaki tabloda (Tablo2) gösterilmiştir.

\begin{tabular}{|c|c|c|c|c|}
\hline \multirow{2}{*}{ GELIRLER } & \multirow{2}{*}{$\begin{array}{c}1489 \\
\text { Tutar (Akçe) }\end{array}$} & \multirow{2}{*}{$\begin{array}{c}1490 \\
\text { Tutar (Akçe) }\end{array}$} & \multicolumn{2}{|c|}{ Finansal Raporlama Çerçeveleri } \\
\hline & & & MSUGT & TMS-TFRS \\
\hline $\begin{array}{l}\text { İstanbul'daki } 12 \text { hamam ve bazı arsaların kira } \\
\text { gelirleri }\end{array}$ & 255.233 & 243.893 & $\begin{array}{l}60 . \\
\text { Brüt Satışlar }\end{array}$ & Esas Faaliyet Gelirleri \\
\hline $\begin{array}{l}\text { İstanbul ve Galata'daki evli erkek ve dul kadın } \\
\text { Hristiyan ve Yahudilerden toplanan cizye gelirleri }\end{array}$ & 433.698 & 421.274 & $\begin{array}{l}602 . \\
\text { Diğer Gelirler }\end{array}$ & Esas Faaliyet Gelirleri \\
\hline $\begin{array}{l}\text { Vakfın, Çorlu, Tekfur Dağı, Ereğli, Kırklareli ve } \\
\text { Edirne'de bulunan elliden fazla köyündeki reayadan } \\
\text { toplanan cizye ve ispence vergisi gelirleri ile para } \\
\text { olarak tahsil edilen diğer vergilerden (mahsulden) } \\
\text { elde edilen gelirler. }\end{array}$ & 723.220 & 708.437 & $\begin{array}{l}602 . \\
\text { Diğer Gelirler }\end{array}$ & Esas Faaliyet Gelirleri \\
\hline $\begin{array}{l}\text { Geçen seneden satılmış olan şeylerden geriye kalan } \\
\text { hububat fazlalarından veya bazı uzak köylerden } \\
\text { nakliye zorluklardan kurtulmak için satılığa } \\
\text { çıkarılmış olan öşür mahsulü ile ambardaki diğer } \\
\text { fazlalıklarının satışından elde edilen gelirler toplamı }\end{array}$ & 88.460 & 76.160 & $\begin{array}{c}679 . \\
\text { Diğer Olağandışı Gelir ve Kârlar }\end{array}$ & Yatırım Faaliyet Gelirleri \\
\hline
\end{tabular}

Yukarıdaki tabloda önceki yıldan devreden gelir bakiyesi, günümüz finansal raporlama çerçeveleri açısından bir varlık statüsünde olup bilançoda (finansal durum tablosu) varlık hesaplarının birinde raporlanmalıdır. Bu bağlamda Muhasebe Sistemi Uygulama Genel Tebliği (MSUGT) açısından "10. Hazır Değerler" hesap grubunda raporlanabilmesi uygun görülürken Türkiye Muhasebe ve Finansal Raporlama Standartları (TMS-TFRS) açısından "Nakit ve Nakit Benzerleri" hesabında raporlanabilir.

Fatih Cami ve İmaret tesisleri için süreklilik arz eden ve esas faaliyetleri içerisinde yer alan kira ve vergi gelirleri ise Muhasebe Sistemi Uygulama Genel Tebliği (MSUGT) açısından “60. Brüt Satışlar” hesap grubunda raporlanabilmesi uygun görülürken Türkiye Muhasebe ve Finansal Raporlama Standartları (TMSTFRS) açısından "Esas Faaliyet Gelirleri” hesap grubunda raporlanabilir.

Benzer şekilde bir yatırım faaliyeti olan hububat stoklarının cari dönemde satılmasından elde edilen gelir ve kârlar ise "679. Diğer Olağandışı Gelir ve Kârlar" hesabında raporlanabilmesi uygun görülürken Türkiye Muhasebe ve Finansal Raporlama Standartları (TMS-TFRS) açısından "Yatırım Faaliyetinden Elde Edilen Gelirler" hesabında raporlanabilir.

Fatih Camii ve İmareti Tesislerinin 1489-1490 yıllarına ait giderleri ile bu giderlerin Muhasebe Sistemi Uygulama Genel Tebliği (MSUGT), Türkiye Muhasebe Standartları (TMS) ve Türkiye Finansal Raporlama Standartları (TFRS) çerçevesinde raporlanacağı hesap sınıfları aşağıdaki tabloda (Tablo3) gösterilmiştir. 
Sakarya Üniversitesi İsletme Enstitüsü Dergisi,(2020): 107-111

Tablo 3. Fatih Camii ve Imareti tesislerinin 1489-1490 yılları giderlerinin günümüz finansal raporlama çerçevelerindeki hesap sınıflaması

\begin{tabular}{|c|c|c|c|c|}
\hline \multirow{2}{*}{ GELIRLER } & \multirow{2}{*}{$\begin{array}{c}1489 \\
\text { Tutar (Akçe) }\end{array}$} & \multirow{2}{*}{$\begin{array}{c}1490 \\
\text { Tutar (Akçe) }\end{array}$} & \multicolumn{2}{|c|}{ Finansal Raporlama Çerçeveleri } \\
\hline & & & MSUGT & TMS-TFRS \\
\hline Vakfın çalışanlarına ödenen maaşlar. & 869.260 & 923.296 & $\begin{array}{c}622 . \\
\text { Satılan Hizmet Maliyeti } \\
- \\
63 . \\
\text { Faaliyet Giderleri }\end{array}$ & $\begin{array}{c}\text { Satılan Hizmet Maliyeti } \\
- \\
\text { Esas Faaliyet Giderleri }\end{array}$ \\
\hline İmarette dağıtılan ekmek ve yiyecek giderleri & 461.417 & 390.803 & $\begin{array}{c}622 . \\
\text { Satılan Hizmet Maliyeti }\end{array}$ & Satılan Hizmet Maliyeti \\
\hline Fatih Camii için yapılan harcamalar & 4.159 & 4.690 & $\begin{array}{c}63 . \\
\text { Faaliyet Giderleri } \\
\end{array}$ & Esas Faaliyet Giderleri \\
\hline Darüşşifada yapılan masraflar & 72.000 & 72.000 & $\begin{array}{c}65 . \\
\text { Diğer Olağan Gider ve Zararları }\end{array}$ & Yardımcı Faaliyet Giderleri \\
\hline Müteferrik giderler & 63.432 & 13.589 & $\begin{array}{c}65 . \\
\text { Diğer Olağan Gider ve Zararları }\end{array}$ & Yardımcı Faaliyet Giderleri \\
\hline Tamirat giderleri & 13.663 & 16.871 & $\begin{array}{c}65 . \\
\text { Diğer Olağan Gider ve Zararları }\end{array}$ & Yardımcı Faaliyet Giderleri \\
\hline
\end{tabular}

Yukarıdaki tabloda "Vakfın Çalışanlarına Ödenen Maaşlar" Muhasebe Sistemi Uygulama Genel Tebliği (MSUGT) açısından "622. Satılan Hizmet Maliyeti" hesabında, yönetici maaşları ise "63. Faaliyet Giderleri" hesap grubunda raporlanabilmesi uygun görülürken Türkiye Muhasebe ve Finansal Raporlama Standartları (TMS-TFRS) açısından "Satılan Hizmet Maliyeti" hesabında veya "Esas Faaliyet Giderleri" hesap grubunda raporlanabilir. İmarette dağıtılan ekmek ve yiyecek giderleri de, MSUGT' a göre "622. Satılan Hizmet Maliyeti" hesabında; TMS-TFRS' ye göre de "Satılan Hizmet Maliyeti" hesabında raporlanmalıdır.

Fatih Cami ve İmaret tesisleri için yapılan harcamalar, Muhasebe Sistemi Uygulama Genel Tebliği (MSUGT) açısından "63. Faaliyet Giderleri" hesap grubunda raporlanmalıyken Türkiye Muhasebe ve Finansal Raporlama Standartları (TMS-TFRS) açısından "Esas Faaliyet Giderleri" hesap grubunda raporlamalıdır.

Fatih Cami ve İmaret tesislerinde, “Darüşşifada Yapılan Masraflar”, “Müteferrik Giderler” ve "Tamirat Giderleri” MSUGT’ a göre “65. Diğer Olağan Gider ve Zararlar" hesabında raporlanabilmesi uygunken Türkiye Muhasebe ve Finansal Raporlama Standartları (TMS-TFRS) açısından "Yardımcı Faaliyet Giderleri" hesabında raporlanmalıdır.

\section{Sonuç}

Osmanlı Devleti muhasebe düzeni ve mali yapısı açısından XV. yüzyıla ayrı bir parantez açılması gerekmektedir. Zira ortasından itibaren yükselme dönemine geçilen bu yüzyılda yaşanan siyasi ve iktisadi gelişmeler muhasebe uygulamaları ve mali yapıyı da etkilemiştir. Özellikle de Fatih Sultan Mehmed dönemindeki kanunnamelerle teşekkül sürecine giren Osmanlı muhasebe sistemi ve mali organizasyonu II. Bayezid dönemindeki iktisadi etkilerle birlikte gelişimini sürdürmüştür. Bu dönemde ticarette yaşanan gelişmelerle birlikte II. Bayezid ile Cem Sultan arasında yaşanan mücadele sonucu ortaya çıkan dönemsel iktisadi sıkıntılar vergilerle ilgili yeni yapısal düzenlemelerle birlikte kayıt ihtiyacının da ortaya çıkmasına zemin hazırlamıştır. Esasen Osmanlı Devleti muhasebe uygulamaları ve mali yapısına ilişkin tüm bu gelişmeleri o dönemden günümüze kadar ulaşan merdiven yöntemi ile tutulmuş bir takım muhasebe kayıtları, çeşitli hesap defterleri ve gelir gider cetvelleri gibi belgelerden izlemek mümkündür. Bu çalışmada da bu belgelerden biri olan ve ilk olarak Barkan (1963) tarafından tetkik edilen Fatih Camii ve İmareti Tesislerinin 1489-1490 yıllarına ait muhasebe kayıtları ele alınmıştır.

Fatih Camii ve İmareti Tesislerinin kayıtları incelendiğinde, gelir kalemleri arasında; önceki yıldan devreden bakiyenin yanı sıra taşınmazlardan elde edilen kira gelirleri, cizye ve vergi gelirleri ile satış gelirlerinin mevcut olduğu görülmüştür. Giderler bölümü ise; vakıf çalışanlara ödenen maaşlar, Fatih Camii ve Darüşşifa için yapılan masraflar, imarette dağıtılan yiyecek giderleri, tamirat giderleri ve diğer çeşitli giderlerden oluşmaktadır. Çalışmada bu gelir ve gider kalemleri tablolar halinde sunularak günümüz Muhasebe Sistemi Uygulama Genel Tebliği (MSUGT), Türkiye Muhasebe Standartları (TMS) ve Türkiye Finansal Raporlama Standartları (TFRS) çerçevesinde raporlanacağı hesap sınıfları tespit edilmiştir. Böylelikle geçmişteki uygulamalar ile günümüz raporlama çerçeveleri arasında bir ilişki kurulmaya çalışımıştır.

Vakfa ait kayıtların, dönemin iktisadi durumu ve Osmanlı Devleti muhasebe uygulamalarının gelişmişlik seviyesi açısından önemli bir gösterge olarak kabul edilebileceğini söylemek mümkündür. Zira beş yüz yılı aşkın bir süre önce, bir vakfın yıllık faaliyetleri sonucunda ortaya çıkan gelir ve giderlerini sınıflandırarak sistematik ve açıklayıcı bir şekilde kaydedip raporlanmış olması Osmanlı Devleti muhasebe uygulamalarının ileri bir seviyede olduğunu göstermekle birlikte devletin denetim ve mali organizasyonunun gücünü de ortaya koymaktadır.

\section{Kaynakça}

Barkan, Ö. L. (1963). Fatih Cami ve İmareti tesislerin 1489-1490 yıllarına ait muhasebe bilançoları. İstanbul Üniversitesi İktisat Fakültesi Mecmuası, (43)1, 297341.

Güvemli, O. (1998). Türk Devletleri muhasebe tarihi, Osmanlı İmparatorluğu (Tanzimat'a kadar) 2. Cilt. İstanbul: Avcıol Yayınları.

Güvemli, O., Toraman, C., ve Güvemli B.. (2015). State Accounting In the Ottoman Empire -Anatolian Accounting Recording Culture- Fist Edition. Ankara: Public Oversight Accounting and Auditing Standarts of Board of Turkey.

Halaçoğlu, Y. (1991). X1V-XVII. Yüzyıllarda Osmanlılarda Devlet Teşkilâtı ve Sosyal Yapı. Ankara: Türk Tarih Kurumu Yayınları.

İnalcık, H. (2009). Osmanlı İmparatorluğu Toplum ve Ekonomi Üzerinde Arşiv Çalışmaları, İncelemeler. 4. Baskı, İstanbul: Eren Yayıncılık.

İnalcık, H. (2015). Devlet-i 'Aliyye Osmanlı İmparatorluğu Üzerine Araştırmalar - I, Klasik Dönem (1302-1606) Siyasal, Kurumsal ve Ekonomik Gelişim. 55. Baskı, İstanbul: Türkiye İş Bankası Kültür Yayınları.

Küçüker, M. (2019). XV. Yüzyıl Osmanlı Devleti muhasebe uygulamalarında yaşanan gelişmeler: Muhyeddin Muhammed'in Mecma'ü’l-Kavâ'id adlı eseri. Yayınlanmamış Doktora Tezi, Sakarya: Sakarya Üniversitesi İşletme Enstitüsü.

Küçüker, M., Can, A.V. ve Demirci, Ş. D. (2018). Muhasebe denetim tarihinde iki önemli kadın: Christine de Pisan ve Ayşe Sultan. 5. Uluslararası Muhasebe ve Finans Araştırmaları Kongresi (ICAFR'18) Bildiriler Kitabı. 599-607.

Öztürk, Y. (1999). Osmanlı klâsik sisteminin teşekkülü ve çözülüşü. Türkiye Günlüğü Dergisi, 58, 133-136.

Öztürk, Y. (2000). Osmanlı Hâkimiyetinde Kefe 1475-1600. Ankara: T.C. Kültür Bakanlığı Milli Kütüphane Basımevi.

Sayar, N. (1978). Türkiye İmparatorluk Dönemi Mali Olayları. İstanbul: İstanbul İktisadi ve Ticari İlimler Akademisi Nihad Sayar Yayın ve Yardım Vakfı Yayınları. Taş, H. (2010). Osmanlı Maliyesinde “Bedel” Uygulaması Üzerine Bir Değerlendirme. İkinci İktisat Tarihi Kongresi Bildiriler -1, Elazığ: Fırat Üniversitesi Yayınları. Uluçay, Ç. (1959). Bayazıd II.'nin aliesi. Tarih Dergisi / Turkish Journal of History 10 (14), 104-124.

Uzunçarşılı, İ. H. (1983). Osmanlı Tarihi 2. Cilt. 4. Baskı, Ankara: Türk Tarih Kurumu Yayınları. 